УДК 659.3

DOI https://doi.org/10.24919/2308-4863/34-1-2

\author{
Наталія АНДРЇ̈В, \\ orcid.org/0000-0001-5410-2078
} кандидат економічних наук, доцент, викладач кафедри сочіокультурної діяльності Ужгородського інституту культури і мистецтв (Ужгород, Україна) n.andriiv6493-7@ubogazici.in

Олександр ГЕРЕШКО, orcid.org/0000-0002-2010-256

викладач кафедри сочуікультурної діяльності Ужггородського інституту культури і мистецттв (Ужгород, Україна) hereshko6493-7@national-univesity.info

Марія МАРТИНЮК, orcid.org/0000-0003-4020-8757 викладач кафедри мистецьких дисичиплін Ужсгородського інституту культури і мистецтв (Ужгород, Україна) m.martyniuk6493-7@kpi.com.de

\title{
МЕНЕДЖМЕНТ СОЦІОКУЛЬТУРНОЇ ДІЯЛЬНОСТІ
}

У цъьому науковому дослідженні обговорюються питання менеджменту соиіокультурної діяльності стосовно умов, щчо склалися у сучасному соиіумі. Численні прочеси організачї сочіокультурної діяльності та управління нею натепер викликають жваве обговорення у сучасних засобах масової інформації, оскільки подібна тематика є вельми важливою з точки зору визначення певної структури постановки питань у сфері соціально-культурних явищ та пошуку иляхів їх якісного розв'язання. Натепер соиіокультурна діяльність дістала суттєвого масштабу, тому питання ї̈ організації та планування, щуо власне і є сутністю менеджменту, потребують якісного висвітлення задля визначення певних умов розв'язання питань сучасного соціокультурного життя. Актуальність заявленої тематики дослідження зумовлюється наявністю певних складнощів упровадження ефективних систем менеджменту соціальної та культурної сфер діяльності, щзо потребують ретельного вивчення та розв'язання. Методологія изього наукового дослідження має у своїй основі поєднання аналітичного методу дослідження питання, щзо винесено у заголовок, із логічним компонуванням результатів иього дослідження із його висновками. Основними результатами иієё наукової роботи слід вважати окреслення головних підходів до об'єктивного висвітлення питань менеджменту соціокультурної діяльності та надання належної оцінки важливості формування ефективної системи менеджменту з точки зору реалій сучасного соиіокультурного життя. Перспективи подальших досліджень у визначеному напрямі зумовлюються необхідністю формування ефективного менеджменту у різних сферах соиіокультурної діяльності та відстеження головних чинників, які мають суттєве значення з точки зору розподілу обов 'язків серед суб'єктів культурного життя сочіуму, щьо формують його характерні риси та здатність до саморозвитку та вдосконалення. Прикладна иінність ицього наукового дослідження полягає у можливості застосувати в практичній сфері головні його результати та висновки з метою покращення якості діяльності наявної нині системи менеджменту соціально-культурної сфери.

Ключові слова: соціокультурна сфера, соціально-культурна діяльність, менеджмент соціокультурної діяльності, основи управління, проблеми спілкування, засоби налагодження комунікащії. 
Nataliia ANDRIIV,

orcid.org/0000-0001-5410-2078

Candidate of Economics, Associate Professor,

Senior Lecturer at the Department of Socio-Cultural Activity

Uzhhorod Institute of Culture and Arts

(Uzhhorod, Ukraine) n.andriiv6493-7@ubogazici.in

Oleksandr HERESHKO, orcid.org/0000-0002-2010-256

Senior Lecturer at the Department of Socio-Cultural Activity Uzhhorod Institute of Culture and Arts (Uzhhorod, Ukraine) hereshko6493-7@national-univesity.info

Mariia MARTYNIUK, orcid.org/0000-0003-4020-8757 Senior Lecturer at the Department of Art Disciplines Uzhhorod Institute of Culture and Arts (Uzhhorod,Ukraine) m.martyniuk6493-7@kpi.com.de

\section{MANAGEMENT OF SOCIO-CULTURAL ACTIVITIES}

This study discusses the management of socio-cultural activities in relation to the conditions prevailing in modern society. Numerous processes of organising and managing sociocultural activities are currently being actively discussed in modern mass media, since such topics are very important from the standpoint of defining a certain structure for raising questions in the field of socio-cultural phenomena and finding ways to qualitatively solve them. At present, socio-cultural activities have reached a significant scale. Therefore, the issues of its organisation and planning, which constitute the essence of management, require quality coverage in order to determine certain conditions for solving problems of modern socio-cultural life. The relevance of the subject is conditioned by the presence of certain difficulties in implementing effective management systems of social and cultural spheres of activity that require careful study and resolution. The methodology of this study is based on a combination of the analytical method of research of the subject matter with the logical collation of the results and conclusions of this study. The main results of this study include the determination of the main approaches to objective coverage of socio-cultural management and provision of a proper evaluation of the importance of developing an effective management system in terms of the realities of modern socio-cultural life. Prospects for further study in a particular direction are conditioned by the need for effective management in various areas of sociocultural activities and tracking the main factors that are significant in terms of distribution of responsibilities among the subjects of cultural life, which shape its features and ability to self-development and improvement. The applied value of this study lies in the ability to apply its main results and conclusions in practice in order to improve the quality of the current management system of the socio-cultural sphere.

Key words: socio-cultural sphere, socio-cultural activity, management of socio-cultural activity, basics of management, problems of communication, means of establishing communication.

Постановка проблеми. У сучасному соціокультурному житті виникає безліч питань, що потребують своєчасної оцінки та розв'язання із застосуванням ефективної системи менеджменту задля повноцінного планування та реалізації програми послідовного розвитку суспільства. Тому питання менеджменту соціокультурної діяльності заслуговують належного вивчення та розв'язання згідно з актуальними потребами сучасного життя.

Слід зазначити, що у сучасній реальності розвитку українського суспільства на теперішньому етапі спостерігаються соціальні, економічні, політичні передумови для переходу до послідовного розвитку сфери культури: накопичується культурний потенціал, що вимагає системних перетворень в організації та управлінні установами та організаціями культури та цільової підтримки найважливіших напрямів їхньої діяльності. Як свідчать численні соціологічні дослідження та опитування населення, рівень життя людей дещо змінюється, а разом 3 ним ростуть і культурні запити населення, насамперед молоді. На цьому тлі накопичився вантаж проблем, пов'язаних перш за все зі скороченням кількості та малою місткістю об'єктів та засобів культури, нераціональним розміщенням їх по територіях проживання населення, недостатньою оснащеністю установ культури сучасним обладнанням, технічними засобами, музичними інструментами, що істотно стримує розвиток соціокультурних процесів, що задовольняють запити та потреби населення (Чижиков, 2013: 209). До цього треба 
долучити фактор недостатнього розуміння деякими суб'єктами значення розвитку соціокультурної сфери життя суспільства у теперішніх умовах та необхідність вжиття додаткових заходів щодо роз'яснення сутності цього питання.

У сучасному стані сфери соціокультурного життя стосовно українських реалій можна вважати значним досягненням формування належних умов щодо розвитку системи менеджменту соціокультурної сфери, здатної ефективно вирішувати питання організації різноманітних заходів покращення культурного складника життя населення та задоволення культурних потреб соціуму. Адже культурний аспект соціального життя $\epsilon$ невід'ємною складовою частиною загального розвитку держави, покращення життя громадян та своєчасного вирішення безлічі питань, що становлять основу соціокультурних потреб населення. На цьому тлі дуже важливими чинниками постають питання розвитку професіоналізму працівників соціокультурної сфери, зміцнення їхнього багажу знань щодо можливостей втілення нових технологічних рішень, здатних суттєво покращити загальний рівень вирішення питань соціокультурної діяльності загалом. Адже, як засвідчує практичний досвід, працівники сфери культури на нинішньому етапі розвитку українського суспільства не завжди володіють достатнім професійним рівнем, ініціативністю й не завжди готові застосовувати нові технології в організації культурнотворчого процесу (Чижиков, 2013: 210).

Як один 3 найбільш ефективних варіантів розвитку сучасної системи менеджменту соціокультурної сфери життя суспільства $\epsilon$ розробка та практичне втілення комплексно-цільових програм щодо покращення умов функціонування різноманітних ланок соціокультурного життя. Планування 3 використанням цільових програм допоможе знайти ефективні шляхи головних проблем культурного життя сучасного суспільства, пов'язаних із складнощами існування вітчизняної соціокультурної сфери у ринкових умовах, що склалися. Культура, перебуваючи в ринковій економіці, виявляється в тій ситуації, коли ринок постійно створює проблеми та водночас пропонує можливості. Та для подальшого якісного використовування цих можливостей, для того щоб вирішувати проблеми, культура змушена запускати проєкти. Іншими словами, проєкти $є$ інструментом адаптації, інструментом розвитку. Але питання викликає те, як ці проєкти запускати. А це питання вже $\epsilon$ головним 3 точку зору функціонування системи менеджменту соціокультурної діяльності та становить їі головне значення та сутність.
Аналіз досліджень. Головні питання менеджменту соціокультурної діяльності 3 точки зору їхньої оцінки у реаліях сучасної соціальної системи знайшли своє якісне відображення у наукових дослідженнях таких авторів, як В. М. Чижиков (2013), И. Ю. Левітіна (2015), В. А. Ропот, К. М. Мартиросян (2018), В. А. Микляєв, Н. Н. Покровська (2016) та інші. Вказані автори компетентно висвітлюють різноманітні аспекти сучасного соціокультурного життя та дають власну оцінку комплексу актуальних питань соціально-культурної сфери життя суспільства 3 точки зору їх можливого розв'язання.

Крім того, у своїх дослідженнях зазначені автори наголошують на наявності багатьох проблем соціокультурної діяльності суспільства та роблять спробу аналізу варіантів їх вирішення. 3 точки зору розвитку менеджменту соціокультурної діяльності дослідження вказаних авторів мають велике значення, оскільки виокремлюють широке коло питань, що потребують ретельного вивчення з метою втілення на практиці досягнутих результатів та сформованих висновків задля створення необхідних умов розвитку культури соціуму та формування нових традицій соціокультурного життя.

Мета статті полягає у визначенні головних чинників формування системи менеджменту соціокультурної сфери сучасного суспільства та окреслення основних напрямів і1ї подальшого розвитку $з$ точки зору створення умов для практичного задоволення культурних проблем громадян та забезпечення якісного розвитку всієї соціокультурної сфери та формування іï нових, стійких та позитивних традицій.

Виклад основного матеріалу. Соціокультурне життя суспільства завжди було предметом жвавих обговорень та диспутів у наукових та соціальних колах, а також висвітлювалося у численних наукових дослідженнях різних авторів. У нинішньому XXI столітті менеджмент соціокультурної діяльності відіграє важливу роль 3 точки зору формування необхідних умов соціального та культурного розвитку, задоволення різноманітних потреб громадян у визначених сферах.

Натепер у системі соціальних наук сформувалися два типові підходи до оцінювання та за наявності такої необхідності змінювання системи менеджменту соціокультурної діяльності: соціоінженерний (переважно «технократичний») та гуманітарний («розуміючий»). 3 ними пов'язані й деякі ідеали науковості та особливості викладання у сучасних вищих навчальних закладах. Так, соціоінженерний підхід найближче стоїть 
до «натуралістичної» гілки соціально-наукового пізнання, коли об'єкт розглядається крізь призму практичної діяльності суб' єкта управління. Що ж стосується гуманітарного підходу, то його головна вимога - дослідити управлінську реальність у контексті смислів, ідеалів та цінностей, якими керуються суб'єкти менеджменту в процесі взаємодії (Резник, 2010: 111).

Звісно, ці два підходи повною мірою не вичерпують усього розмаїття парадигм менеджменту у контексті соціокультурної діяльності. Але можливості якісного вирішення комплексу питань у контексті розвитку соціальної та культурної сфер життя суспільства завдяки наявності конкретних типологій їх вирішення суттєво розширюються, чому активно сприяють зазначені підходи. Крім того, варто відзначити, що для якісного вирішення питань соціокультурної діяльності суспільства від представника системи менеджменту вимагається здатність якісно оцінювати складність виникаючих питань та вміння швидко знаходити шляхи їх ефективного розв'язання.

Важливі якості, якими повинен володіти майбутній соціальний менеджер, - високі інтелектуальні здібності та перш за все здатність до аналізу проблемних ситуацій, креативність, здатності до організації взаємодії, високі особистісні та морально етичні якості (принциповість, чесність, напористість та ініціативність). Але головне, що обов'язково слід ураховувати у процесі підготовки такого фахівця, - це орієнтація на управління процесами, що мають місце у сучасній соціальній сфері. Соціальний менеджмент як професія - це насамперед діяльність у сфері управління. Тому й фахівець у цій галузі повинен бути підготовлений як управлінець, причому не просто як керівник, а саме як управлінець, який володіє необхідними знаннями, компетенціями та досвідом (Резник, 2011: 124).

Питання менеджменту соціокультурної діяльності передбачають необхідність визначення головних напрямів діяльності, що підпадають під коло відповідальності працівників сфери менеджменту та зумовлюють необхідність наявності в них певних компетенцій у зв'язку з цим. Звісно, менеджмент у такому контексті - вельми специфічна діяльність, що поєднує в собі безліч різних аспектів: філософію, економіку, безпосередньо менеджмент та маркетинг, психологію, право, комунікацію тощо. Крім того, творча сфера нині має безпрецедентно велике поширення: соціальне та просторово-територіальне. А однією 3 головних дійових осіб цієї системи залишається сам менеджер, який розуміє задум, зміст та творчу структуру, який супроводжує та контролює процеси створення та подальшої реалізації твору, представлення його публіці.

Соціум та різноманітні форми соціальнокультурної діяльності служать основним фундаментом, що об'єднує нині гігантську різнорідну культурну індустрію. Особливості інноваційного менеджменту у сфері культури наочно проявляються у створенні відповідних спеціалізованих структур незвичайного формату, де тісно переплітається діяльність представників з різних культурних ланцюжків. Такі аргументи дозволяють сформулювати поняття «інноваційна політика в сфері культури», яка полягає в комплексі актуальних заходів, що вживаються різними соціокультурними інститутами (одиничними або ланцюговими) 3 розробки, впровадження, підтримки організаційно-управлінських, сервісних, матеріально-технічних, фінансових, інтелектуальних інновацій у зовнішньому та внутрішньому галузевому середовищі (Резник, 2009: 106). Універсальність наведених інновацій незаперечна, вони розраховані на різну аудиторію - людей різного віку, інтересів, смаків, захоплень, спроможностей. Доцільно організувати професійний консалтинг для фахівців сфери культури та соціального середовища, що займаються підготовкою та проведенням різних видів заходів, з вигідним обміном «ноу-хау».

Подібний комплексній підхід до питань соціокультурної діяльності сприяє удосконаленню діяльності системи менеджменту соціокультурної сфери у сучасних умовах. Своєчасне та якісне урегулювання всіх проблем, що виникають на цьому тлі, є ознакою професійної зрілості представників менеджменту соціокультурної діяльності та їхньої здатності адекватно реагувати на потреби сьогодення. Адже цьому повинно сприяти створення якісної системи підготовки менеджерів зазначеного роду діяльності. Такий підхід відповідає вимогам самої соціальної практики.

Як підтверджує досвід західних країн, соціальний менеджер виступає в різних професійних позиціях та ролях. Як соціальний клініцист він повинен мати психологічну освіту та орієнтуватися в основному на роботу 3 окремими клієнтами або групами клієнтів. Як організаційний (управлінський) консультант він займається обслуговуванням соціальних організацій загалом, вивченням їхньої культури та організаційної структури (Волков, 2014: 98). На цій посаді він має справу найчастіше не з рядовими працівниками організації, а з iї верхнім ешелоном - адміністрацією, управлінським персоналом. Для цього йому необхідно отримати соціологічну або соціально-антропологічну 
освіту. Він виступає також як реальний управлінець, що здатен ефективно діяти в умовах складної ринкової ситуації та приносити прибуток або іншу вигоду своїй окремій організації. Для цього йому потрібно опанувати нову спеціальність «Менеджмент» (Щебланова, Санкова, 2005: 165).

Визначення основних проблем соціокультурної діяльності також є одним 3 головних завдань менеджменту. Без якісного та своєчасного розв'язання наявних проблемних питань не можна вести мову щодо ефективності менеджменту соціокультурної сфери. На цьому тлі варто відзначити важливість своєчасного набуття життєвого досвіду, необхідного для якісного розуміння всіх виникаючих питань. Менеджмент у сфері соціально-культурних відносин потребує наявності багатьох навичок ефективного управління, отримати які можливо виключно практичним шляхом у процесі здійснення управлінської діяльності.

Сучасна соціально-культурна сфера $\epsilon$ пріоритетною базою для створення, поширення та розвитку інновацій, які пов'язані з формуванням та реалізацією нової культурної політики, появою нового типу установ, розширенням спектра послуг, що надаються, галузей (підгалузей, індустрій), розвитком творчих процесів та необхідністю розробки нестандартних підходів до вирішення багатьох організаційно-творчих проблем (Ратманова, 2018: 15). Тому менеджмент соціокультурної діяльності $є$ творчою сферою, що потребує прояву творчої уяви, здатності шукати та знаходити нестандартні рішення зовні звичайних ситуацій. Відзначимо, що характер, умови та специфіка соціокультурної сфери життя суспільства передбачають першочергову необхідність в удосконаленні іï функціонування. Соціокультурна сфера являє собою органічний синтез безлічі галузей, культурних підгалузей, креативних, творчих індустрій, якими користуються різні кола населення, та щоразу потрібно задовольнити їхні запити на найвищому і креативному за рішенням рівні.

Слід звернути увагу на той факт, що у сучасній науці практично відсутні розроблені практичні рекомендації щодо вдосконалення різноманітних аспектів соціокультурного життя, особливо стосовно творчих підходів до розвитку менеджменту сфери, що обговорюється. Це зумовлює потребу в узагальненні інновацій, що стосуються переліку комплексних напрямів функціонування соціально-культурної сфери. Організаційно-управлінські та економічні аспекти діяльності менеджера соціокультурної діяльності, пов'язані із залученням уваги потенційних та заможних клієнтів, доповнюються педагогічними аспектами. До них можна віднести особистий приклад менеджера, його всебічну турботу про відвідувача та ступінь доступності послуг для клієнта, зміст сценаріїв, постановок, культурних програм, акцій, що передають основну ідею, мету, завдання вибору того чи іншого заходу в будь-якій соціально-культурній індустрії та ï конкретному технологічному ланцюжку (Ратманова, 2018: 17).

Сучасна соціокультурна сфера дуже швидко розвивається, і цей факт зумовлює необхідність швидкого реагування наявної системи менеджменту на всі зміни, що мають місце у сучасному соціальному та культурному житті. 3'являються новітні культурні течії та традиції, що потребують від соціальних менеджерів адекватного сприйняття та формування об'єктивної оцінки ступеня їхнього впливу на настрої сучасного покоління та рівень його культурної освіченості загалом. Від своєчасної та якісної оцінки новітніх явищ культурного життя сучасного суспільства багато в чому залежить рівень культури соціуму у майбутньому, а також інтелектуальне та психічне здоров'я нації.

3 огляду на це можна вважати необхідною розробку та втілення комплексу заходів щодо покращення загального рівня культурної освіченості представників системи менеджменту соціокультурної сфери з метою формування у них потрібних навичок щодо якісного аналізу процесів, що мають місце у сучасному соціокультурному житті. Це стосується всіх без винятку ланок системи менеджменту, задіяних у різних сферах соціокультурного життя суспільства. Розробка належної наукової бази у контексті питань, що висвітлюються, лише сприятиме якісному вирішенню зазначеної проблеми.

Програми соціального та культурного розвитку окремих регіонів держави також сприятимуть підвищенню загального соціокультурного рівня життя у країні та являють собою сферу безпосередньої відповідальності структур менеджменту соціокультурної діяльності. Реалізація подібних програм сприяє створенню резервів саморозвитку та відтворення, що властиві культурі, призведе до оновлення організаційного та управлінського зв'язку, має активно сприяти формуванню нового стилю вирішення численних питань взаємодії центру 3 регіонами. 3'являється реальний механізм залучення діячів культури до процесів розробки різноманітних аспектів культурної політики, конкурсного розподілу коштів, формується необхідна свобода від бюрократичного апарату тощо (Чижиков, 2013: 213) 
Наслідками цього процесу закономірно стане створення необхідного міцного зв'язку між представниками системи менеджменту соціокультурної сфери та конкретними виконавцями на місцях. Це сприятиме створенню сприятливих умов для вирішення безлічі питань соціокультурного життя та суттєво підвищить авторитет соціокультурних менеджерів, що своєю чергою сприятиме подальшому розвитку системи соціокультурного менеджменту в умовах сучасного суспільства.

Таким чином, аналіз факторів розвитку системи менеджменту соціокультурної діяльності свідчить про наявність значного потенціалу у цій сфері та необхідності його якісного використання у майбутньому. Подальші наукові розробки у зазначеному напрямі сприятимуть більш повному розкриттю тематики дослідження та формуванню більш повних висновків 3 урахуванням новітніх тенденцій у функціонуванні менеджменту соціокультурної діяльності.

Висновки. Нині проблеми цілісності суспільства, національної безпеки, інтеграції України у світове співтовариство вимагають аналізу механізму взаємодій у соціокультурному житті країни трьох мегафакторів, що характеризують специфіку постмодерну: бурхливого розвитку науки та техніки, усвідомлення численних лімітів суспіль- ного розвитку й глобалізації. У цьому контексті важливими завданнями системи менеджменту соціокультурної діяльності є створення необхідних умов щодо гармонійного поєднання у сучасному суспільстві основних тенденцій розвитку у рамках визначених напрямів. Адже без створення необхідних умов позитивного соціокультурного розвитку країни неможливо вести мову щодо подальшої розбудови національної самосвідомості та формування потрібних орієнтирів соціального та культурного життя.

Менеджмент соціокультурної діяльності $\epsilon$ складним поняттям, від якісного розуміння сутності якого та ефективного впровадження його принципів багато в чому залежить стан різних сфер сучасного життя загалом. Це накладає додаткову відповідальність на якість підготовки майбутніх представників зазначеної системи менеджменту та зумовлює актуальність всебічного висвітлення різноманітних аспектів їхньої діяльності. Цьому певною мірою мають активно сприяти подальші наукові розробки у визначеному напрямі, що будуть відбуватися за умов виникнення необхідності додаткового вивчення питань, винесених у заголовок цього наукового дослідження, у разі суттєвих соціокультурних змін у суспільстві в майбутньому.

\section{СПИСОК ВИКОРИСТАНИХ ДЖЕРЕЛ}

1. Волков Е. Н. Социальная инженерия: Явление и его концептуализация. Вестник Нижегородского университета им. Н. И. Лобачевского. Серия: Соииальные науки. 2014. № 3 (35). С. 96-101.

2. Левитина И. Ю. Особенности менеджмента в социокультурной системе продюсирования творческой деятельности. Культурная жизнь Юга России. 2015. № 5. С. 153-156.

3. Микляев В. А., Покровская Н. Н. Социокультурная укорененность экономической деятельности как основа социального менеджмента. Ученые записки Санкт-Петербургского университета управления и экономики. 2016. № 2 (54). C. 43-55.

4. Ратманова С. В. Використання інноваційного потенціалу сфери культури як першочергова наукова проблема. Інновації в науиі. 2018. № 4 (80). С. 15-21.

5. Резник Ю. М. Социальная инженерия как профессия. Известия Томского политехнического университета. Инжиниринг ГЕОРЕСУРС. 2011. № 6. С. 124-130.

6. Резник Ю. М. Социально-гуманитарные технологии управления: специфика и возможности применения. Вестник Рязанского государственного университета им. С. А. Есенина. 2010. № 5. С. 111-126.

7. Резник Ю. М. Социокультурный подход к управлению: анализ и конструирование. Вестник Нижегородского университета им. Н. И. Лобачевского. Серия: Соџиальные науки. 2009. № 2. С. 104-110.

8. Ропот В. А., Мартиросян К. М. Формування знань про менеджмент соціально-культурної сфери в педагогіці вищої школи. Проблеми сучасної педагогічної освіти. 2018. № 8. С. 239-241.

9. Чижиков В. М. Целевые программно-проектные технологии менеджмента социокультурной деятельности. Вестник Московского государственного университета культуры и искусств. 2013. № 3 (53). С. 209-214.

10. Щебланова В. В., Санкова К. А. Анализ социокультурных контекстов современности. Вестник Саратовского государственного технического университета. 2005. № 3 (8). С. 165-168.

\section{REFERENCES}

1. Chizhikov V. M. Tselevyye programmno-proyektnyye tekhnologii menedzhmenta sotsiokul'turnoy deyatel'nosti [Target program-design technologies of management of socio-cultural activity]. Bulletin of the Moscow State University of Culture and Arts, 2013, No. 3 (53), pp. 209-214 [in Russian].

2. Levitina I. Yu. Osobennosti menedzhmenta v sotsiokulturnoy sisteme prodyusirovaniye tvorcheskoy deyatelnosti [Features of management in the sociocultural system of producing creative activity]. Cultural Life of the South of Russia, 2015, No. 5, pp. 153-156 [in Russian]. 
3. Miklyaev V. A., Pokrovskaya N. N. Sotsiokulturnaya ukorenennost ekonomicheskoy deyatelnosti kak osnova sotsialnogo menedzhmenta [Sociocultural rootedness of economic activity as the basis of social management]. Scientific Notes of the St. Petersburg University of Management and Economics, 2016, No. 2 (54), pp. 43-55 [in Russian].

4. Ratmanova S. V. Vykorystannya innovatsiynoho potentsialu sfery kultury yak pershocherhova naukova problema [The use of innovative potential in the field of culture as a priority scientific problem]. Innovations in Science, 2018, No. 4 (80), pp. 15-21 [in Ukrainian].

5. Reznik Yu. M. Sotsialnaya inzheneriya kak professiya [Social engineering as a profession]. Bulletin of the Tomsk Polytechnic University. Engineering GEORESURS, 2011, No. 6, pp. 124-130 [in Russian].

6. Reznik Yu. M. Sotsialno-gumanitarnyye tekhnologii upravleniya: spetsifika i vozmozhnosti primeneniya [Social and humanitarian management technologies: Specificity and possibilities of application]. Ryazan State University Bulletin named after S. A. Yesenin, 2010, No. 5, pp. 111-126 [in Russian].

7. Reznik Yu. M. Sotsiokulturnyy podkhod k upravleniyu: Analiz i konstruirovaniye [Sociocultural approach to management: Analysis and design]. Bulletin of the Nizhny Novgorod University named after N. I. Lobachevsky. Series: Social Sciences, 2009, No. 2, pp. 104-110 [in Russian].

8. Ropot V. A., Martirosyan K. M. Formuvannya znan pro menedzhment sotsialno-kulturnoyi sfery v pedahohitsi vyshchoyi shkoly [Formation of knowledge about the management of socio-cultural sphere in higher school pedagogy]. Problems of Modern Pedagogical Education, 2018, No. 8, pp. 239-241 [in Ukrainian].

9. Shcheblanova V. V., Sankova K. A. Analiz sotsiokulturnykh kontekstov sovremennosti [Analysis of socio-cultural contexts of our time]. Bulletin of the Saratov State Technical University, 2005, No. 3 (8), pp. 165-168 [in Russian].

10. Volkov E. N. Sotsialnaya inzheneriya: yavleniye i yego kontseptualizatsiya [Social engineering: Phenomenon and its conceptualization]. Bulletin of the Nizhny Novgorod University named after N. I. Lobachevsky. Series: Social Sciences, 2014, No. 3 (35), pp. 96-101 [in Russian]. 